\title{
Association of candy consumption with body weight measures, other health risk factors for cardiovascular disease, and diet quality in US children and adolescents: NHANES 1999-2004
}

\author{
Carol E. O'Neil ${ }^{\prime *}$, Victor L. Fulgoni $\|^{2}$ and Theresa A. Nicklas ${ }^{3}$ \\ 'Louisiana State University Agricultural Center, Baton Rouge, LA, USA; ${ }^{2}$ Nutrition Impact, LLC, Battle Creek, MI, USA; \\ ${ }^{3}$ Department of Pediatrics, USDA/ARS Children's Nutrition Research Center, Baylor College of Medicine, Houston, \\ TX, USA
}

\section{Abstract}

Objective: The purpose of this study was to determine the effects of total, chocolate, or sugar candy consumption on intakes of total energy, fat, and added sugars; diet quality; weight/adiposity parameters; and risk factors for cardiovascular disease in children 2-13 years of age $(n=7,049)$ and adolescents $14-18$ years $(n=4,132)$ participating in the 1999-2004 National Health and Nutrition Examination Survey.

Methods: Twenty-four hour dietary recalls were used to determine intake. Diet quality was determined using the Healthy Eating Index-2005 (HEI-2005). Covariate-adjusted means, standard errors, and prevalence rates were determined for each candy consumption group. Odds ratios were used to determine the likelihood of associations with weight status and diet quality.

Results: In younger children, total, chocolate, and sugar candy consumption was $11.4 \mathrm{~g} \pm 1.61,4.8 \mathrm{~g} \pm 0.35$, and $6.6 \mathrm{~g} \pm 0.46$, respectively. In adolescents, total, chocolate, and sugar candy consumption was $13.0 \mathrm{~g} \pm 0.87$, $7.0 \mathrm{~g} \pm 0.56$, and $5.9 \mathrm{~g} \pm 0.56$, respectively. Total candy consumers had higher intakes of total energy $(2248.9$ kcals \pm 26.8 vs $1993.1 \mathrm{kcals} \pm 15.1, p<0.0001)$ and added sugars $(27.7 \mathrm{~g} \pm 0.44$ vs $23.4 \mathrm{~g} \pm 0.38, p<0.0001)$ than non-consumers. Mean HEI-2005 score was not different in total candy and sugar candy consumers as compared to non-consumers, but was significantly lower in chocolate candy consumers $(46.7 \pm 0.8$ vs $48.3 \pm$ $0.4, p=0.0337)$. Weight, body mass index (BMI), waist circumference, percentiles/ $z$-score for weight-for-age and BMI-for-age were lower for candy consumers as compared to non-consumers. Candy consumers were 22 and $26 \%$, respectively, less likely to be overweight and obese than non-candy consumers. Blood pressure, blood lipid levels, and cardiovascular risk factors were not different between total, chocolate, and sugar candy consumers and non-consumers (except that sugar candy consumers had lower C-reactive protein levels than non-consumers).

Conclusion: This study suggests that candy consumption did not adversely affect health risk markers in children and adolescents.

Keywords: children; adolescents; candy; chocolate; sugar candy; added sugars; discretionary calories; nutrient intake; dietary adequacy; health risk factors; healthy eating index; NHANES

Received: II November 20I0; Revised: I February 20I I; Accepted: 17 May 201 I; Published: I4 June 20I I

$\mathrm{T}$ he prevalence of overweight and obesity in pediatric populations remains high; in 2007-2008, $16.9 \%$ of children were obese (Body Mass Index [BMI]-for-age percentile $\geq 95$ ) and $31.7 \%$ of children were overweight (BMI-for-age percentile $\geq 85$ to $<95$ ) (1). No statistically significant linear trends in high BMI were found over the time periods 1999-2000, 2001-2002, 2003-2004, 2005-2006, and 2007-2008 except among the heaviest males 6-19 years of age. Current cutoffs for BMI in children can be used as an indication of adiposity (2).

Obesity in children increases the risk of diseases previously seen mostly in adults, including hyperlipidemia 
(3), hypertension (3), metabolic syndrome (4), and type 2 diabetes (4). Overweight children also suffer from diminished health-related quality of life (5), bullying/teasing (6), and low self-esteem (7). Body mass index and waist circumference (WC) can also identify children and adolescents with a clustering of cardiovascular risk factors (8). Although studies are contradictory, overweight in children may serve as a harbinger of adult disease (9). Overweight/obesity in childhood tracks into adulthood (10). Thus, it is important to understand the factors associated with pediatric obesity.

One factor that may contribute to excess energy intake is the consumption of discretionary calories $(11,12)$. The 2005 Dietary Guidelines for Americans (DGA) included a recommendation for discretionary calories that were defined as the difference between energy requirements and essential energy needed to meet recommended intakes (13). The concept of discretionary calories was translated into MyPyramid recommendations for consumers (14). The maximum number of discretionary calories recommended ranges from 100 to 300 kcals depending on age, gender, and physical activity level. The Healthy Eating Index-2005 (HEI) (15), which measures diet quality and adherence to the 2005 DGA, also includes discretionary calories. Solid fats, alcohol, and added sugars (AS) are major sources of discretionary calories. The 2010 Dietary Guidelines Advisory Committee, however, suggested moving away from the concept of discretionary calories (16). Regardless, candy is a food source of calories.

Intake of candy in US children is not well defined. Bachman et al. (17), did not provide the absolute intake of candy but showed using data from the National Health and Nutrition Examination Survey (NHANES) 20012002 that candy was the fifth highest contributor of AS to the diet $(6.2 \%$ of total AS) and was the sixth highest contributor of oils (4.6\% of total oils). In 2008, per capita domestic disappearance of all candy/confectionery products was 21.7 pounds (18). Per capita food availability data do not account for waste in the marketing system or the home; thus, data typically overestimate actual consumption. Candy has been shown to be the second most frequently purchased category of items (21.3\% of all items) by children from 'corner stores' (19). It has also been shown that the percentage of children consuming candy fell from $94 \%$ in 1973 to $71 \%$ in 1994, and that in that time, the gram amount of candy consumed fell from $45 \mathrm{~g}$ to approximately $35 \mathrm{~g}$ (20).

Candy consumption has been associated with dental caries in children $(21,22)$, although caries development is dependent on factors other than just fermentable carbohydrate substrate in the mouth. These include oral hygiene, dental care, and fluoride use $(23,24)$. The effect of candy on weight and other health indicators is not well established, although it is intuitive that candy consumption would be positively associated with weight. Consumption of 'sweets,' including, but not limited to candy, has been shown to be positively associated with weight (25) in children. In contrast, candy intake was inversely associated with weight in a longitudinal study of Swedish children (26). The goal of this study was to examine further the association between intake of candy and weight/adiposity, diet quality, and health risk indicators using a nationally representative sample of children.

\section{Subjects and methods}

\section{Study population}

Data from children and adolescents 2-18 years of age $(n=11,182)$ participating in the NHANES 1999-2000, 2001-2002, and 2003-2004 were combined for these analyses to increase sample size. Groups excluded from the analyses were females who were pregnant and/or lactating $(n=91)$, and those with 24-hour recall data judged to be incomplete or unreliable by the USDA's Food Surveys Research Group. This study was exempted by the Louisiana State University Agricultural Center's Institutional Review Board.

\section{Collection of dietary intake data}

Dietary intake data were obtained from in-person 24hour dietary recall interviews administered using an automated multiple-pass method $(27,28)$. Parents/guardians of children 2-5 years provided the 24-hour dietary recalls; children (6-11 years) were assisted by an adult; and all others provided their own recall. For data collection years 1999-2002, only a single 24-hour dietary recall was collected. Beginning in 2003-2004, two 24-hour dietary recalls were collected; however, to ensure consistency within this study only data from the in-person interview (first recall) were used. Descriptions of the dietary interview methods are provided in the NHANES Dietary Interviewer's Training Manual; these include pictures of the Computer-Assisted Dietary Interview system screens, measurement guides, and charts that were used to collect dietary information (29).

\section{Candy consumption and nutrient intake data}

The survey food codes in USDA 1994-1998 Survey Nutrient Database (30) and the Food and Nutrient Database for Dietary Studies (FNDDS), Versions 1.0 (31) and 2.0 (32) were used in NHANES 1999-2002 and 2003-2004, respectively, to determine intake of candy. Candy consumers were defined as those participants consuming any amounts of candy/confection except gum and were placed in one of three consumption groups: (a) any candy/confection (chocolate candy, sugar candy), (b) chocolate candy only, and (c) sugar candy 
only. To assess intake of energy, total fat, saturated fatty acids (SFA), and AS, the Food and Nutrient Database for Dietary Studies, versions 1 (31) and 2 (32) were used in NHANES, 2001-2002 and 2003-2004, respectively. The USDA 1994-1998 Survey Nutrient Database was used to process the dietary interview data in NHANES 1999-2000 (30).

\section{The healthy eating index (HEl-2005)}

The HEI-2005 was used to determine diet quality $(15,33$, 34). The SAS code used to calculate HEI-2005 scores was downloaded from the Center for Nutrition Policy and Promotion website (35).

\section{Physiologic measures}

Height and weight were obtained according to NHANES protocols (36). Body Mass Index was calculated as body weight (kilogram) divided by height (meters) squared. The percentile and $z$-score of BMI-for-age was calculated using the Statistical Analysis Software (SAS) program for Growth Charts available from the Centers for Disease Control and Prevention (CDC) (37). Overweight was defined as a gender-and-specific BMI between the 85th and $<95$ th percentile and obese was defined as a BMI $\geq$ 95th percentile (38). Several measures of weight and adiposity were used in this study to look at the reliability in the results. The measures included BMI, BMI-percentile of weight for age, BMI-percentile of BMI for age, BMI $z$-score of BMI for age, $z$-score of weight for age, and triceps skinfolds.

Waist circumference (36), blood pressure (39), laboratory values of serum lipids (40), and other cardiovascular risk factors were determined according to NHANES protocols.

\section{Statistical analysis}

Sample-weighted data were used and all analyses were performed using SAS and SUDAAN Release 9.0.1 (Research Triangle Institute, Research Triangle Park, NC) to adjust the variance for the complex sample design. For the years 1999-2004, a 6-year weight variable was created by assigning two-thirds of the 4-year weight for 1999-2002 if the person was sampled in 1999-2002 and assigning one-third of the 2-year weight for 20032004 if the person was sampled in 2003-2004. The 6-year sample weights were used in analyses of intake, body measurements, blood pressure, and laboratory data.

Analyses of health parameters were adjusted for gender, ethnicity, age, and other relevant covariates (see footnote in tables for specifics). For certain analyses, selfreported exercise levels were used as a covariate; when inclusion of exercise in the regression models reduced the significance of the relationship of candy consumption with dependent variables of interest, the relationship was considered attenuated. Logistic regression was used to assess the risk of lower HEI-2005 scores, overweight, and obesity for candy consumers and non-consumers. Data are presented as means \pm standard errors, and a $p$-value of $<0.05$ was deemed significant. To further evaluate the association of candy intake with food/nutrient intake and health, we used methods of Huang et al. (41) to determine implausible energy intakes and certain analyses were re-run to assess the impact of eliminating subjects with energy intakes too high or too low as related to expected energy requirements.

\section{Results}

\section{Demographics}

Table 1 shows the demographics of the sample for children 2-13 years $(n=7,049)$ and adolescents $14-18$ years $(n=4,132)$. In children, a higher percentage of females than males consumed total candy $(p=0.0024)$; there was also a race/ethnicity difference among total candy ( $p=$ $0.0064)$, chocolate candy $(p=0.0125)$, and sugar candy ( $p=0.0001)$ consumers compared with non-consumers. Chocolate candy consumers were also older $(8.0 \pm 1.6$ vs $7.6 \pm 0.05$ years, $p=0.0222$ ) than non-chocolate consumers. In adolescents, a higher percentage of females than males consumed total candy ( $p=0.0007)$, chocolate candy (0.0024), and sugar candy $(p=0.0234)$. There was a race/ ethnicity difference among total $(p<0.0001)$, chocolate ( $p=0.0064)$, and sugar candy $(p=0.0001)$ consumers when compared with non-consumers.

\section{Candy consumption}

In children $2-13$ years, the total ( $11.4 \mathrm{~g} \pm 1.61$ vs $35.2 \mathrm{~g} \pm$ 1.4), chocolate (4.8 $\mathrm{g} \pm 0.35$ vs $35.8 \mathrm{~g} \pm 1.7)$, and sugar (6.6 $\mathrm{g} \pm 0.46$ vs $29.0 \mathrm{~g} \pm 1.3$ ) candy consumption for the total population and candy consumers only, respectively (Table 2). In adolescents, per capita and candy consumer intake was $13.0 \mathrm{~g} \pm 0.87$ vs $46.2 \mathrm{~g} \pm 1.4,7.0 \mathrm{~g} \pm 0.56$ vs $48.4 \mathrm{~g} \pm 2.0$, and $5.9 \mathrm{~g} \pm 0.56$ vs $36.1 \mathrm{~g} \pm 3.2$ for total candy, chocolate candy, and sugar candy, respectively (Table 2).

\section{Nutrient intake and HEl-2005 scores}

Total candy consumers had higher intakes of energy (2248.9 kcals \pm 26.8 vs 1993.1 kcals $\pm 15.1, p<0.0001)$ and AS $(27.7 \pm 0.44$ vs $23.4 \pm 0.38, p<0.0001)$ than nonconsumers (Table 3 ). Chocolate candy consumers had higher intakes of energy ( $2333.8 \mathrm{kcals} \pm 52.2$ vs 2031.2 kcals $\pm 13.3, p<0.0001)$, total fat $(79.0 \mathrm{~g} \pm 0.85$ vs 75.2 $\mathrm{g} \pm 0.40, p=0.0001)$, SFA ( $28.8 \mathrm{~g} \pm 0.37$ vs $26.5 \mathrm{~g} \pm 0.16$, $p<0.0001)$, and AS $(27.7 \mathrm{~g} \pm 0.71$ vs $24.3 \mathrm{~g} \pm 24.3 \pm 0.34$, $p<0.0001)$ than non-consumers. Sugar candy consumers had higher intakes of energy $(2254.3 \pm 29.4$ vs $2024.4 \pm$ $13.4, p<0.0001)$ and $\mathrm{AS}(28.4 \pm 0.51$ vs $23.8 \pm 0.34$, 
Table 1. Demographics of total, chocolate, and sugar candy consumers and non-consumers 2-13 years and 14-18 years: National Health and Nutrition Examination Survey 1999-2004

\begin{tabular}{|c|c|c|c|c|c|c|c|c|c|}
\hline \multirow[b]{2}{*}{ Age group } & \multicolumn{2}{|c|}{ Total candy-gum } & \multirow[b]{2}{*}{$P$-value } & \multicolumn{2}{|c|}{ Chocolate candy } & \multirow[b]{2}{*}{$P$-value } & \multicolumn{2}{|c|}{ Sugar candy } & \multirow[b]{2}{*}{$P$-value } \\
\hline & $\begin{array}{l}\text { Consumers } \\
\text { Mean } \pm \text { SE }\end{array}$ & $\begin{array}{c}\text { Non-consumers } \\
\text { Mean } \pm \text { SE }\end{array}$ & & $\begin{array}{l}\text { Consumers } \\
\text { Mean } \pm \text { SE }\end{array}$ & $\begin{array}{c}\text { Non-consumers } \\
\text { Mean } \pm \text { SE }\end{array}$ & & $\begin{array}{l}\text { Consumers } \\
\text { Mean } \pm \text { SE }\end{array}$ & $\begin{array}{c}\text { Non-consumers } \\
\text { Mean } \pm \text { SE }\end{array}$ & \\
\hline \multicolumn{10}{|l|}{$2-13$ years } \\
\hline Numbers & $n=2,234$ & $n=4,815$ & & $n=857$ & $n=6,192$ & & $n=I, 594$ & $n=5,455$ & \\
\hline Gender & & & 0.0024 & & & 0.4983 & & & 0.9928 \\
\hline Males & $4 I . I \pm 3.4$ & $52.7 \pm I . I$ & & $49.3 \pm 2.9$ & $51.3 \pm 0.88$ & & $51.3 \pm 2.2$ & $51.0 \pm 0.92$ & \\
\hline Females & $58.9 \pm 3.4$ & $47.3 \pm 1.1$ & & $50.7 \pm 2.9$ & $48.7 \pm 0.88$ & & $48.8 \pm 2.2$ & $49.0 \pm 0.92$ & \\
\hline Race/ethnicity & & & 0.0064 & & & 0.0125 & & & 0.0001 \\
\hline NH-White & $71.8 \pm 2.6$ & $70.8 \pm 2.1$ & & $76.7 \pm 2.8$ & $68.8 \pm 2.0$ & & $69.8 \pm 2.4$ & $68.8 \pm 2.1$ & \\
\hline NH-Black & $18.6 \pm 2.2$ & $16.2 \pm 1.5$ & & $11.8 \pm 1.8$ & $17.2 \pm 1.7$ & & $18.9 \pm 2.0$ & $15.7 \pm 1.6$ & \\
\hline Mexican Hispanic & $9.6 \pm 1.7$ & $13.0 \pm 1.6$ & & $11.4 \pm 1.8$ & $15.0 \pm 1.6$ & & $11.3 \pm 1.5$ & $15.5 \pm 1.7$ & \\
\hline Age (years) & $7.8 \pm 0.10$ & $7.6 \pm 0.05$ & 0.0619 & $8.0 \pm 0.16$ & $7.6 \pm 0.05$ & 0.0222 & $7.8 \pm 0.11$ & $7.6 \pm 0.05$ & 0.1077 \\
\hline$\% \leq$ PIR I. 85 & $46.9 \pm 3.2$ & $44.7 \pm 2.0$ & 0.5474 & $48.3 \pm 3.5$ & $51.2 \pm 1.7$ & 0.4245 & $47.6 \pm 2.6$ & $51.7 \pm 1.7$ & 0.1155 \\
\hline \multicolumn{10}{|l|}{$14-18$ years } \\
\hline Numbers & $n=I, 224$ & $n=2,908$ & & $n=587$ & $n=3,545$ & & $n=745$ & $n=3,387$ & \\
\hline Gender & & & 0.0007 & & & 0.0024 & & & 0.0234 \\
\hline Males & $44.2 \pm 2.2$ & $53.6 \pm 1.2$ & & $4 I . I \pm 3.4$ & $52.7 \pm I . I$ & & $45.0 \pm 2.8$ & $52.1 \pm 1.2$ & \\
\hline Females & $55.8 \pm 2.2$ & $46.4 \pm 1.2$ & & $58.9 \pm 3.4$ & $47.3 \pm 1.1$ & & $55.0 \pm 2.8$ & $47.9 \pm 1.2$ & \\
\hline Race/ethnicity & & & $<0.0001$ & & & 0.0064 & & & 0.0001 \\
\hline NH-White & $67.8 \pm 2.3$ & $72.3 \pm 2.1$ & & $71.8 \pm 2.6$ & $70.8 \pm 2.1$ & & $64.7 \pm 2.6$ & $72.3 \pm 2.0$ & \\
\hline NH-Black & $20.9 \pm 2.2$ & $14.8 \pm 1.5$ & & $18.6 \pm 2.2$ & $16.2 \pm 1.5$ & & $23.6 \pm 2.5$ & $15.2 \pm 1.5$ & \\
\hline Mexican & $11.4 \pm 1.5$ & $12.9 \pm 1.6$ & & $9.6 \pm 1.7$ & $13.0 \pm 1.6$ & & $11.7 \pm 1.6$ & $12.6 \pm 1.6$ & \\
\hline \multicolumn{10}{|l|}{ Hispanic } \\
\hline Age (years) & $16.0 \pm 0.06$ & $16.0 \pm 0.03$ & 0.9551 & $16.1 \pm 0.9$ & $16.0 \pm 0.03$ & 0.1726 & $15.9 \pm 0.07$ & $16.0 \pm 0.04$ & 0.4047 \\
\hline$\% \leq$ PIR I.85 & $46.3 \pm 2.3$ & $44.5 \pm 2.1$ & 0.5184 & $46.9 \pm 3.2$ & $44.7 \pm 2.0$ & 0.5474 & $44.4 \pm 2.6$ & $45.1 \pm 1.9$ & 0.8021 \\
\hline
\end{tabular}

Data are presented as sample-weighted means \pm SD.

Abbreviations: $\mathrm{NH}$, non-Hispanic; PIR, poverty income ratio. 
Table 2. Mean amount of candy consumed in grams by children 2-13 years and adolescents $14-18$ years in candy consumption groups

\begin{tabular}{|c|c|c|c|c|c|c|}
\hline \multirow[b]{2}{*}{ Age group } & \multicolumn{2}{|c|}{ Total candy } & \multicolumn{2}{|c|}{ Chocolate candy } & \multicolumn{2}{|c|}{ Sugar candy } \\
\hline & Consumers & Per capita & Consumers & Per capita & Consumers & Per capita \\
\hline $2-13$ years & $35.2 \pm 1.4$ & $11.4 \pm 1.6 \mathrm{I}$ & $35.8 \pm 1.7$ & $4.8 \pm 0.35$ & $29.0 \pm 1.3$ & $6.6 \pm 0.46$ \\
\hline Number & 2,234 & 7,049 & 857 & 7,049 & I,594 & 7,049 \\
\hline $14-18$ years & $46.2 \pm 2.2$ & $13.0 \pm 0.87$ & $48.4 \pm 2.0$ & $7.0 \pm 0.56$ & $36.1 \pm 3.2$ & $5.9 \pm 0.56$ \\
\hline Number & 1,224 & 4,132 & 587 & 4,132 & 745 & 4,132 \\
\hline
\end{tabular}

Data are presented as sample-weighted means $\pm S D$ and numbers.

$p<0.0001)$, and lower intakes of total fat $(72.8 \pm 0.55$ vs $76.4 \pm 0.43, p<0.0001)$ and SFA $(25.6 \pm 0.28$ vs $27.1 \pm$ $0.17, p<0.0001)$ than non-consumers.

Mean HEI-2005 score was not different in total candy or sugar candy consumers as compared to non-consumers. However, the mean HEI-2005 score was significantly lower in chocolate candy consumers as compared to non-consumers ( $46.7 \pm 0.8$ vs $48.3 \pm 0.4, p=0.0337$ ) (Table 3 ). Results using reduced data set eliminating implausible intake provided similar results to those above.

\section{Anthropometrics, blood pressure, and laboratory values}

Mean adjusted levels of adiposity measures by candy consumption category are presented in Table 4. Total candy consumers had a significantly lower weight $(42.1 \mathrm{~kg} \pm$ 0.32 vs $43.5 \mathrm{~kg} \pm 0.27 ; p=0.0001)$, BMI $(19.5 \pm 0.12$ vs $20.1 \pm 0.10 ; p<0.0001)$, WC $(67.7 \mathrm{~cm} \pm 0.35$ vs $68.9 \mathrm{~cm} \pm$ $0.28 ; p=0.0001)$, triceps skinfolds $(13.6 \mathrm{~mm} \pm 0.25$ vs $14.0 \mathrm{~mm} \pm 0.13 ; p=0.0334$ ), percentiles $/ z$-scores for weight-for-age $(59.1 \pm 0.71$ vs $63.5 \pm 0.77,0.35 \pm 0.03$ vs $0.51 \pm 0.03$, respectively; both $p<0.0001$ ), and percentiles $/ z$-scores for BMI-for-age ( $57.8 \pm 0.92$ vs $62.7 \pm 0.76$, $0.28 \pm 0.03$ vs $0.47 \pm 0.03$; both $p<0.0001)$ than nonconsumers. Weight, BMI, and WC analyses were re-run adjusting for self-reported moderate/vigorous or vigorous physical activity and this did not change the results (data not shown). Chocolate candy consumers had a lower weight (41.9 $\mathrm{kg} \pm 0.46$ vs $43.3 \mathrm{~kg} \pm 0.27, p=0.0147$ ), shorter stature $(140.1 \mathrm{~cm} \pm 0.29$ vs $141.0 \mathrm{~cm} \pm 0.17, p=$ 0.0295 , lower WC $(67.8 \mathrm{~cm} \pm 0.42$ vs $68.6 \mathrm{~cm} \pm 0.29, p=$ $0.0448)$, and lower percentile BMI-for-age $(58.9 \pm 1.3$ vs $61.6 \pm 0.79, p=0.0352$ ) than non-consumers. Sugar candy consumers had a lower weight $(41.9 \mathrm{~kg} \pm 0.39$ vs 43.4 $\mathrm{kg} \pm 0.25, p=0.0004)$, BMI (19.5 \pm 0.13 vs $20.1 \pm 0.10$, $p<0.0001)$, WC $(67.6 \mathrm{~cm} \pm 0.38$ vs $68.8 \mathrm{~cm} \pm 0.27, p=$ $0.0004)$, triceps skinfold ( $13.5 \mathrm{~mm} \pm 0.28$ vs $14.0 \mathrm{~mm} \pm$ $0.14, p=0.0356$ ), and percentile/ $z$-score for BMI-for-age $(58.7 \pm 1.3$ vs $62.8 \pm 0.99, p=0.0167 ; 0.31 \pm 0.05$ vs $0.48 \pm$ $0.03, p=0.0164$, respectively) than non-consumers.

There were no differences in children regarding the likelihood to have a high quality diet, defined by HEI (80th percentile or better), among all three groups of candy consumers and non-consumers (Table 5). Using
CDC growth charts to assess weight status, candy consumers were $22 \%$ less likely $(p<0.0001)$ to be overweight and $26 \%$ less likely to be obese $(p<0.0001)$ than non-consumers (Table 5). Sugar candy consumers were $21 \%$ less likely ( $p=0.0015)$ to be overweight and $20 \%$ less likely to be obese $(p=0.0150)$ than non-consumers.

The only physiologic parameter that was different was a lower C-reactive protein level of sugar candy consumers and non-consumers $(0.12 \mathrm{mg} / \mathrm{dL} \pm 0.01 \mathrm{vs} 0.15 \mathrm{mg} / \mathrm{dL} \pm$ $0.01, p=0.0085$ ) (Table 6).

\section{Discussion}

These data showed that nearly $32 \%$ of children and $30 \%$ of adolescents reported consuming candy the day of the recall. These figures are much lower than those shown in the Bogalusa Heart Study (BHS) (20) potentially showing that candy consumption decreased from 1993-1994 to 1999-2004. That study, which also used 24-hour diet recall methodology, showed that in 1973-1974, 94\% of 10-year-old children consumed candy and in 1993-1994, $71 \%$ of 10 -year-old children consumed candy. In that study, the diets of children of one age only were examined, a limited geographic range was examined, and participants were limited to black/white. Although we were unable to find a study examining geographic differences in candy intake in children, a recent study of adults showed that energy intake from candy was higher in Southeast Louisiana than in Los Angeles County (12). Additional studies assessing geographic variation in candy consumption are needed.

Consumption of candy in this study was modest. There are few studies with which to compare these results. For the BHS study, Nicklas et al. (20) showed that in 19731974, intake in 10-year-old children was $45.0 \mathrm{~g}$ and in 1993-1994, intake was $34.8 \mathrm{~g}$; however, it was not clear if this was per capita consumption or reflected the intake of consumers only. Dietary data were obtained using 24hour recalls; although the multiple pass method used in NHANES provides more accurate data than other recall methods $(27,28)$, over- and under-reporting may still occur. Individuals may selectively under-report foods generally known to be high in fats, carbohydrates, and sugars (42). Foods with a 'negative health image' may be 


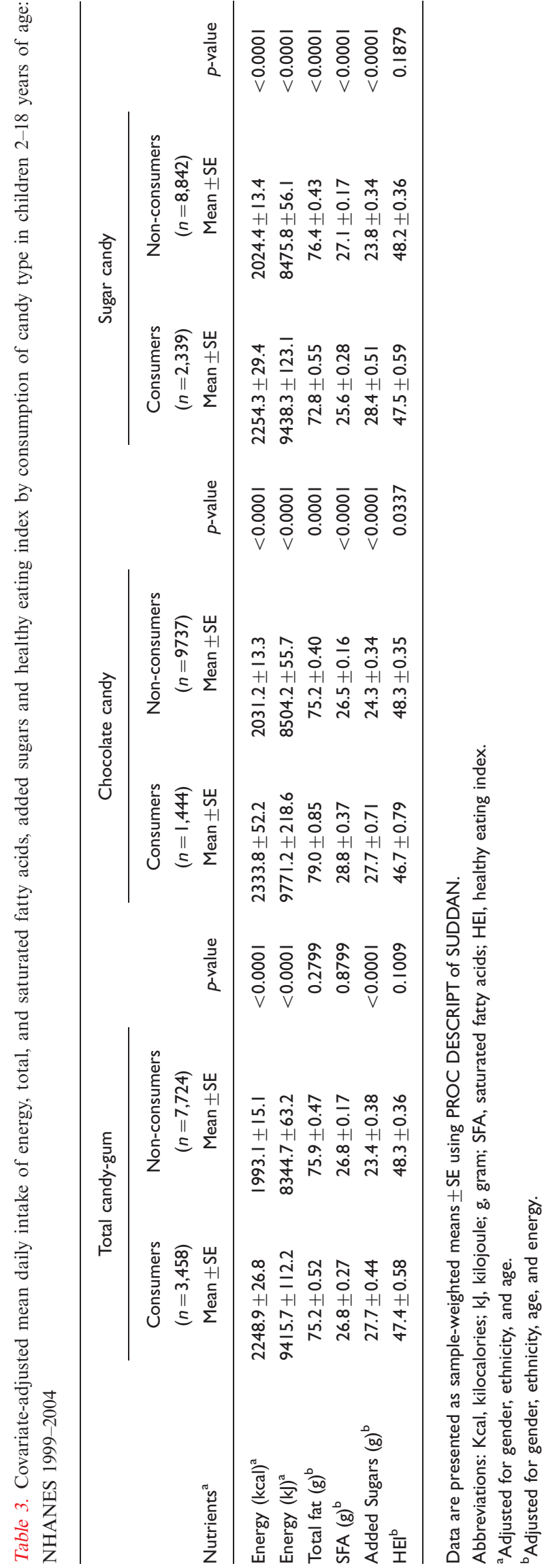

subject to higher levels of under-reporting than other foods (43). Since candy is a food potentially influenced by reporting errors, individuals with implausible intakes (41) were excluded from the data set and the reported relationships remained.

This study showed that in total, chocolate, and sugar candy consumers, total energy intake was higher when compared with non-consumers. Using nationally representative data sets, from 1977 to 2006, energy from candy consumed as snacks by children increased from 5.7 to $8.5 \%$, although values were modest when compared with other snack foods such as desserts and sweetened beverages (44). Despite the higher intake of energy by candy consumers, consumption was not associated with higher levels of any weight parameter, but was associated with a lower risk of overweight and obesity. Future studies should include assessment of overall dietary and physical activity patterns of candy consumers, but longitudinal studies are needed to understand more fully the relationship between higher energy intake and its association with weight in candy consumers.

The Institute of Medicine (IOM) recommends that the population consume no more than $25 \%$ of energy from AS (45). Overall, candy consumers also had higher intakes of AS than non-consumers; however, mean energy from AS in consumers of total, chocolate, and sugar candy was only $4.9 \%, 4.7 \%$, and $6.3 \%$, respectively. Candy contributed very low levels of AS to the diet.

The IOM recommendation for AS was based, in part, on the finding that AS in excess of $25 \%$ showed the greatest decline in micronutrient dilution (45). The majority of studies have suggested that consumption of foods high in AS were associated with poor overall diet quality (46-50), whereas two reviews have failed to provide conclusive evidence that AS affects diet quality $(51,52)$. Overall, diet quality in this study was very poor in all groups, whether or not candy was consumed. Diet quality was lower only in chocolate candy consumers. This may be because of the increased intake of SFA, a component in calculating the HEI-2005 (15), in chocolate candy consumers. That SFA intake was higher in chocolate candy consumers was not surprising since SFA are found in higher proportions than unsaturated fatty acids in cocoa butter. Cacao seeds contain a significant amount of fat (40-50\% as cocoa butter) (53), but the fat content of chocolate candy is influenced not only by the percentage of cacao solids but by addition of other ingredients, e.g. milk or cream (54).

The higher SFA intake may also be of concern from a standpoint of changes in serum lipid levels or other biomarkers of cardiovascular disease; however, recent evidence has questioned the role of SFA as a risk factor in heart disease (55). Children are less likely than adults to have lipid derangements; however, with the increasing levels of overweight and obesity in children, lipid levels 
Table 4. Covariate-adjusted mean anthropometric measures in children 2-18 years of age by consumption of candy type

\begin{tabular}{|c|c|c|c|c|c|c|c|c|c|}
\hline \multirow{3}{*}{ Measure } & \multicolumn{2}{|c|}{ Total candy } & \multirow{3}{*}{$p$-value } & \multicolumn{2}{|c|}{ Chocolate candy } & \multirow{3}{*}{$p$-value } & \multicolumn{2}{|c|}{ Sugar candy } & \multirow{3}{*}{$p$-value } \\
\hline & $\begin{array}{l}\text { Consumers } \\
(n=3,458)\end{array}$ & $\begin{array}{c}\text { Non-consumers } \\
(n=7,724)\end{array}$ & & $\begin{array}{l}\text { Consumers } \\
(n=1,444)\end{array}$ & $\begin{array}{c}\text { Non-consumers } \\
(n=9,737)\end{array}$ & & $\begin{array}{l}\text { Consumers } \\
(n=2,339)\end{array}$ & $\begin{array}{c}\text { Non-consumers } \\
(n=8,842)\end{array}$ & \\
\hline & Mean \pm SE & Mean \pm SE & & Mean \pm SE & Mean \pm SE & & Mean \pm SE & Mean \pm SE & \\
\hline Weight $(\mathrm{kg})^{\mathrm{a}}$ & $42.1 \pm 0.32$ & $43.5 \pm 0.27$ & 0.0001 & $41.9 \pm 0.46$ & $43.3 \pm 0.27$ & 0.0147 & $41.9 \pm 0.39$ & $43.4 \pm 0.25$ & 0.0004 \\
\hline Height $(\mathrm{cm})^{\mathrm{a}}$ & $141.0 \pm 0.16$ & $140.8 \pm 0.18$ & 0.4863 & $140.1 \pm 0.29$ & $141.0 \pm 0.17$ & 0.0295 & $141.2 \pm 0.22$ & $140.8 \pm 0.16$ & 0.0537 \\
\hline BMI $\left(\mathrm{kg} / \mathrm{m}^{2}\right)^{\mathrm{a}}$ & $19.5 \pm 0.12$ & $20.1 \pm 0.10$ & $<0.0001$ & $19.6 \pm 0.16$ & $20.0 \pm 0.10$ & 0.0537 & $19.5 \pm 0.13$ & $20.1 \pm 0.10$ & $<0.0001$ \\
\hline WC $(\mathrm{cm})^{\mathrm{a}}$ & $67.7 \pm 0.35$ & $68.9 \pm 0.28$ & 0.0001 & $67.8 \pm 0.42$ & $68.6 \pm 0.29$ & 0.0448 & $67.6 \pm 0.38$ & $68.8 \pm 0.27$ & 0.0004 \\
\hline Triceps SF $(\mathrm{mm})^{\mathrm{a}}$ & $13.6 \pm 0.25$ & $14.0 \pm 0.13$ & 0.0334 & $14.0 \pm 0.27$ & $13.8 \pm 0.15$ & 0.4405 & $13.5 \pm 0.28$ & $14.0 \pm 0.14$ & 0.0356 \\
\hline Percentile for weight-for-age & $59.1 \pm 0.71$ & $63.5 \pm 0.77$ & $<0.0001$ & $59.8 \pm 1.3$ & $62.5 \pm 0.79$ & 0.0792 & $61.5 \pm 1.7$ & $63.6 \pm 0.89$ & 0.2582 \\
\hline$z$-score for weight-for-age ${ }^{\mathrm{b}}$ & $0.35 \pm 0.03$ & $0.51 \pm 0.03$ & $<0.0001$ & $0.38 \pm 0.04$ & $0.47 \pm 0.03$ & 0.1071 & $0.43 \pm 0.06$ & $0.51 \pm 0.04$ & 0.2645 \\
\hline Percentile BMI-for-age ${ }^{\mathrm{b}}$ & $57.8 \pm 0.92$ & $62.7 \pm 0.76$ & $<0.0001$ & $58.9 \pm 1.3$ & $61.6 \pm 0.79$ & 0.0352 & $58.7 \pm 1.3$ & $62.8 \pm 0.99$ & 0.0167 \\
\hline$z$-score for BMI-for-age ${ }^{b}$ & $0.28 \pm 0.03$ & $0.47 \pm 0.03$ & $<0.0001$ & $0.31 \pm 0.05$ & $0.43 \pm 0.03$ & 0.0522 & $0.31 \pm 0.05$ & $0.48 \pm 0.03$ & 0.0164 \\
\hline
\end{tabular}

Source: NHANES 1999-2004, 2-18 years of age, excluding pregnant/lactating females http://www.cdc.gov/nchs/nhanes.htm.

Abbreviations: SE, Standard Error; kg, kilogram; cm, centimeter; m, meter; BMI, body mass index; WC, waist circumference; SF, skinfold.

${ }^{a}$ Adjusted for gender, ethnicity, age, and energy.

${ }^{\mathrm{b}}$ Adjusted for gender, ethnicity, and energy. 


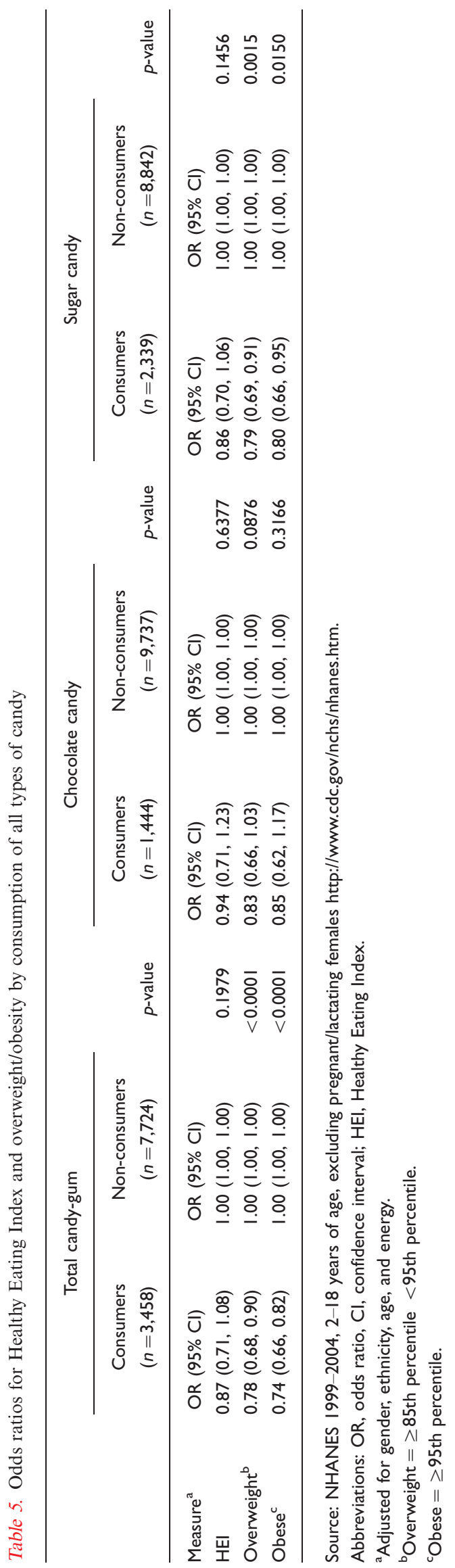

and other cardiovascular risk factors have become of concern in pediatric populations (56). Palmitic and stearic acids constitute the main types of SFA (57) in cocoa butter. Stearic acid is unique among saturated fats in that it is not associated with the low density lipoprotein cholesterol raising potential of other SFA $(58,59)$. Diet can influence lipid levels in children (60), so it would not have been surprising to find that consumption of chocolate candy modified lipid levels in children. However, unlike studies with adults that have shown that chocolate consumption may improve lipid profiles (61-63), no differences were seen in any lipid markers. These findings may have resulted from the relatively small sample size for chocolate consumers or the type of chocolate consumed, since dark chocolate with a high cacao content or cocoa is associated with the greatest improvement in lipids $(64,65)$.

\section{Limitations}

NHANES is a cross-sectional study; thus, cause and effect associations cannot be drawn. Twenty-four hour dietary recalls have several inherent limitations. They may not reflect usual intake and they depend on memory. Parents/guardians reported or assisted with the 24-hour recalls of children 2-11 years of age; whereas parents often report accurately what children eat at home, (66) but may not know what their children eat outside the home (67) that could result in reporting errors (68). In children and adolescents, a greater degree of underreporting has been shown as relative adiposity increased $(69,70)$, which may have accounted for the results. To help obviate this potential problem, implausible energy intakes were deleted from the data set (41). Finally, chocolate candies were combined into a single group; thus, potential effects of dark chocolate could not be assessed.

\section{Conclusions}

This study showed that approximately one-third of children and adolescents consumed candy the day of the recall and that candy consumption was associated with higher intakes of energy and added sugars; chocolate candy consumption was also associated with higher total and SFA intake. Total, chocolate, and sugar candy consumption was not associated with weight/adiposity variables and candy consumers were less likely to be overweight or obese than non-candy consumers. Only chocolate candy consumers had a lower diet quality than non-consumers, but all individuals had poor diet quality regardless of whether they consumed candy. Current levels of candy consumption were not associated with adverse health parameters in children or adolescents. 
Table 6. Adjusted mean physiologic measures for total candy-gum, chocolate candy, and sugar candy consumers 2-18 years

\begin{tabular}{|c|c|c|c|c|c|c|c|c|c|c|}
\hline \multirow[b]{2}{*}{ Measure } & \multirow[b]{2}{*}{$n$} & \multicolumn{3}{|c|}{ Total candy-gum } & \multicolumn{3}{|c|}{ Chocolate candy } & \multicolumn{3}{|c|}{ Sugar candy } \\
\hline & & Consumers & Non-consumers & $p$-value & Consumers & Non-consumers & $p$-value & Consumers & Non-consumers & $p$-value \\
\hline $\mathrm{SBP}, \mathrm{mmHg}^{\mathrm{a}}$ & 7,581 & $105.8 \pm 0.40$ & $106.3 \pm 0.32$ & 0.2759 & $105.3 \pm 0.53$ & $106.3 \pm 0.29$ & 0.0827 & $105.9 \pm 0.47$ & $\mid 06.2 \pm 0.31$ & 0.5250 \\
\hline $\mathrm{DBP}, \mathrm{mmHg}^{\mathrm{a}}$ & 7,581 & $59.7 \pm 0.48$ & $59.3 \pm 0.32$ & 0.4349 & $60.1 \pm 0.58$ & $59.3 \pm 0.29$ & 0.1292 & $59.8 \pm 0.53$ & $59.4 \pm 0.31$ & 0.3299 \\
\hline $\mathrm{HDL}-\mathrm{C}, \mathrm{mg} / \mathrm{dL}^{\mathrm{b}}$ & 2,835 & $54.9 \pm 0.82$ & $53.0 \pm 0.73$ & 0.0707 & $54.6 \pm 1.4$ & $53.4 \pm 0.63$ & 0.4487 & $55.2 \pm 0.84$ & $53.2 \pm 0.70$ & 0.0797 \\
\hline LDL-C, mg/dL ${ }^{\mathrm{b}}$ & 3,826 & $92.4 \pm 1.0$ & $93.3 \pm 0.71$ & 0.3924 & $93.7 \pm 1.5$ & $92.8 \pm 0.70$ & 0.5692 & $92.5 \pm 1.3$ & $93.1 \pm 0.65$ & 0.6295 \\
\hline $\mathrm{TG}, \mathrm{mg} / \mathrm{dL}^{\mathrm{a}}$ & 3,840 & $87.2 \pm 2.0$ & $91.3 \pm 2.1$ & 0.1174 & $86.2 \pm 2.9$ & $90.6 \pm 1.9$ & 0.2165 & $88.1 \pm 2.3$ & $90.4 \pm 1.8$ & 0.3286 \\
\hline Serum folate, $\mathrm{ng} / \mathrm{mL}^{\mathrm{c}}$ & 9,140 & $16.4 \pm 0.23$ & $16.1 \pm 0.20$ & 0.1395 & $16.4 \pm 0.31$ & $16.1 \pm 0.19$ & 0.3578 & $16.3 \pm 0.26$ & $16.1 \pm 0.20$ & 0.4172 \\
\hline Folate, $\mathrm{RBC}, \mathrm{ng} / \mathrm{mL}^{\mathrm{c}}$ & 9,233 & $267.9 \pm 2.6$ & $268.2 \pm 2.4$ & 0.8994 & $267.1 \pm 4.4$ & $268.3 \pm 2.0$ & 0.7808 & $266.7 \pm 2.2$ & $268.5 \pm 2.4$ & 0.4881 \\
\hline Homocysteine, $\mu g / \mathrm{mL}^{\mathrm{c}}$ & 5,835 & $5.2 \pm 0.05$ & $5.3 \pm 0.05$ & 0.4283 & $5.2 \pm 0.08$ & $5.3 \pm 0.04$ & 0.7684 & $5.2 \pm 0.07$ & $5.3 \pm 0.04$ & 0.3110 \\
\hline $\mathrm{CRP}, \mathrm{mg} / \mathrm{dL}^{\mathrm{d}}$ & 9,226 & $0.15 \pm 0.02$ & $0.14 \pm 0.01$ & 0.6099 & $0.20 \pm 0.04$ & $0.14 \pm 0.01$ & 0.1492 & $0.12 \pm 0.01$ & $0.15 \pm 0.01$ & 0.0085 \\
\hline
\end{tabular}

Source: NHANES 1999-2004, ages 2-18 years of age, excluding pregnant/lactating females http://www.cdc.gov/nchs/nhanes.htm.

Abbreviations: Kg, kilograms; cm, centimeters; BMI, Body Mass Index; m, meters; WC, waist circumference; SF, skinfold; mm, millimeter; SBP, systolic blood pressure; Hg, mercury; DBP, diastolic blood pressure; HDL-C, high density lipoprotein-cholesterol; mg, milligram; dL, deciliter; LDL-C, low density lipoprotein-cholesterol; TG, triglycerides; RBC, red blood cell; ng, nanogram; mL, milliliter; $\mu$, microgram; CRP, C-reactive protein.

${ }^{a}$ Adjusted for gender, ethnicity, age, BMI, and energy.

${ }^{b}$ Adjusted for gender, ethnicity, age, BMl, energy, and saturated fatty acids and cholesterol intake.

'Adjusted for gender, ethnicity, age, BMl, energy, folate, and vitamins B6 and BI2.

${ }^{\mathrm{d}}$ Adjusted for gender, ethnicity, age, and energy. 


\section{Conflict of interest and funding}

This research project was supported by the USDA Agricultural Research Service through specific cooperative agreement 58-6250-6-003. Partial support was received from the USDA Hatch Project LAB 93951. Partial support was also received from the National Confectioners Association. None of the funding agencies played any role in the design, analysis, or writing of this manuscript. The authors have no conflicts of interest to declare.

\section{Acknowledgements}

This work is a publication of the United States Department of Agriculture (USDA/ARS) Children's Nutrition Research Center, Department of Pediatrics, Baylor College of Medicine, and Houston, Texas. The contents of this publication do not necessarily reflect the views or policies of the USDA, nor does mention of trade names, commercial products, or organizations imply endorsement from the US government.

\section{References}

1. Ogden CL, Carroll MD, Curtin LR, Lamb MM, Flegal KM. Prevalence of high body mass index in US children and adolescents, 2007-2008. JAMA 2010; 303: 242-9.

2. Flegal KM, Ogden CL, Yanovski JA, Freedman DS, Shepherd JA, Graubard BI, et al. High adiposity and high body mass index-for-age in US children and adolescents overall and by race-ethnic group. Am J Clin Nutr 2010; 91: 1020-26.

3. Ford ES, Mokdad AH, Ajani UA. Trends in risk factors for cardiovascular disease among children and adolescents in the United States. Pediatrics 2004; 114: 153444.

4. Dhuper S, Cohen HW, Daniel J, Gumidyala P, Agarwalla V, St Victor R, et al. Utility of the modified ATP III defined metabolic syndrome and severe obesity as predictors of insulin resistance in overweight children and adolescents: a crosssectional study. Cardiovasc Diabetol 2007; 6: 4 . DOI: 10.1186/1475-2840-6-4

5. Schwimmer JB, Burwinkle TM, Varni JW. Health-related quality of life of severely obese children and adolescents. JAMA 2003; 289: 1813-9.

6. Janssen I, Craig WM, Boyce WF, Pickett W. Associations between overweight and obesity with bullying behaviors in school-aged children. Pediatrics 2004; 13: 1187-94.

7. Strauss RS. Childhood obesity and self-esteem. Pediatrics 2000; 105: e15.

8. Adegboye AR, Andersen LB, Froberg K, Sardinha LB, Heitmann BL. Linking definition of childhood and adolescent obesity to current health outcomes. Int J Pediatr Obes 2010; 5: $130-42$.

9. Yarnell JW, Patterson CC, Thomas HF, Sweetnam PM. Comparison of weight in middle age, weight at 18 years, and weight change between, in predicting subsequent 14 year mortality and coronary events: Caerphilly Prospective Study. J Epidemiol Community Health 2000; 54: 344-8.

10. Freedman DS, Khan LK, Serdula MK, Ogden CL, Dietz WH. Racial and ethnic differences in secular trends for childhood BMI, weight, and height. Obesity (Silver Spring) 2006; 14: $301-8$.
11. Cohen DA, Sturm R, Lara M, Gilbert M, Gee S. Discretionary calorie intake a priority for obesity prevention: results of rapid participatory approaches in low-income US communities. J Public Health (Oxf) 2010; 32: 379-86.

12. Cohen DA, Sturm R, Scott M, Farley TA, Bluthenthal R. Not enough fruit and vegetables or too many cookies, candies, salty snacks, and soft drinks? Public Health Rep 2010; 125: 88-95.

13. Dietary Guidelines for Americans, 2005. Washington, DC: U.S. Department of Health and Human Services and U.S. Department of Agriculture. http://www.health.gov/dietaryguidelines/ dga2005/document/html/executivesummary.htm [cited 18 July 2010].

14. USDA, Center for Nutrition Policy and Promotion. MyPyramid food intake patterns. http://www.mypyramid.gov/downloads/ MyPyramid_Food_Intake_Patterns.pdf. [cited 24 April 2010].

15. Guenther PM, Reedy J, Krebs-Smith SM, Reeve BB, Basiotis PP. Development and evaluation of the healthy eating index2005: technical report. Center for Nutrition Policy and Promotion, U.S. Department of Agriculture. http://www.cnpp.usda. gov/HealthyEatingIndex.htm [cited 24 April 2010].

16. USDA. 2010 dietary guidelines advisory committee report. http://www.cnpp.usda.gov/DGAs2010-DGACReport.htm [cited 27 October 2010].

17. Bachman JL, Reedy J, Subar AF, Krebs-Smith SM. Sources of food group intakes among the US population, 2001-2002. J Am Diet Assoc 2008; 108: 804-14.

18. USDA. Economic Research Service. Food availability data sets. http://www.ers.usda.gov/Data/FoodConsumption/FoodAvailSpread sheets.htm\#sweets [cited 14 July 2010].

19. Borradaile KE, Sherman S, Vander Veur SS, McCoy T, Sandoval B, Nachmani J, et al. Snacking in children: the role of urban corner stores. Pediatrics 2009; 124: 1293-98.

20. Nicklas TA, Demory-Luce D, Yang SJ, Baranowski T, Zakeri I, Berenson G. Children's food consumption patterns have changed over two decades (1973-1994): the Bogalusa Heart Study. J Am Diet Assoc 2004; 104: 1127-40.

21. Källestål C, Fjelddahl A. A four-year cohort study of caries and its risk factors in adolescents with high and low risk at baseline. Swed Dent J 2007; 31: 11-25.

22. Ollila P, Larmas M. A seven-year survival analysis of caries onset in primary second molars and permanent first molars in different caries risk groups determined at age two years. Acta Odontol Scand 2007; 65: 29-35.

23. Gibson S, Williams S. Dental caries in pre-school children: associations with social class, toothbrushing habit and consumption of sugars and sugar-containing foods. Caries Res 1999; 33: 101-13.

24. Van Loren C. Diet and dental caries: cariogenicity may depend more on oral hygiene using fluorides than on diet or type of carbohydrates. Eur J Pediat Dent 2000; 1: 55-62.

25. Nicklas TA, Yang SJ, Baranowski T, Zakeri I, Berenson G. Eating patterns and obesity in children. The Bogalusa Heart Study. Am J Prev Med 2003; 25: 9-16.

26. Huus K, Brekke HK, Ludvigsson JF, Ludvigsson J. Relationship of food frequencies as reported by parents to overweight and obesity at 5 years. Acta Paediatr 2009; 98: 139-43.

27. Moshfegh AJ, Rhodes DG, Baer DJ, Murayi T, Clemens JC, Rumpler WV, et al. The US Department of Agriculture Automated Multiple-Pass Method reduces bias in the collection of energy intakes. Am J Clin Nutr 2008; 88: 324-32.

28. Blanton CA, Moshfegh AJ, Baer DJ, Kretsch MJ. The USDA Automated Multiple-Pass Method accurately estimates group total energy and nutrient intake. J Nutr 2006; 136: 2594-9.

29. The NHANES 2003-2004 dietary interviews procedure manual. Hyattsville, MD: National Center for Health Statistics. 
http://www.cdc.gov/nchs/data/nhanes/nhanes_03_04/DIETARY_ MEC.pdf [cited 30 March 2010].

30. USDA, Agricultural Research Service. Continuing survey of food intakes by individuals 1994-1996, 1998 [CM-ROM; NTIS No. PB2000-500027] 2000.

31. USDA Food and Nutrient Database for Dietary Studies, 1.0 Documentation and User Guide. http://www.ars.usda.gov/ services/docs.htm?docid=7673 [cited 18 December 2009].

32. USDA Food and Nutrient Database for Dietary Studies, 2.0 Documentation and User Guide. http://www.ars.usda.gov/ SP2UserFiles/Place/12355000/pdf/fndds2_doc.pdf\#title [cited 2 March 2009].

33. Guenther PM, Reedy J, Krebs-Smith SM. Development of the healthy eating index-2005. J Am Diet Assoc 2008; 108: 1896 1901.

34. Guenther PM, Reedy J, Krebs-Smith SM, Reeve BB. Evaluation of the healthy eating index-2005. J Am Diet Assoc 2008; 108: 1854-64.

35. Center of Nutrition Policy and Health Promotion. http:// www.cnpp.usda.gov/HealthyEatingIndex-2005report.htm. [cited 18 December 2009].

36. National Health and Nutrition Examination Survey. Anthropometry procedures manual. Revised 2004. http://www.cdc.gov/ nchs/data/nhanes/nhanes_03_04/BM.pdf [cited 19 December 2009].

37. Centers of Disease Control and Prevention. 2000 CDC growth charts for the United States: methods and development. Vital Health Stat 2002; 11: 246.

38. Centers for Disease Control and Prevention. Defining childhood overweight and obesity. http://www.cdc.gov/obesity/childhood/ defining.html [cited 24 April 2010].

39. NHANES 2001-2002 Data Release; May 2004. MEC Examination. Blood pressure section of the physician's examination. http://www.cdc.gov/nchs/data/nhanes/nhanes_01_02/bpx_b_doc. pdf [cited 10 June 2010].

40. NHANES Documentation, codebook, and frequencies: survey years 2003-2004. MEC laboratory component: triglycerides and LDL-cholesterol. http://www.cdc.gov/nchs/data/nhanes/ nhanes_03_04/113am_c.pdf [cited 12 June 2010].

41. Huang TT, Roberts SB, Howarth NC, McCrory MA. Effect of screening out implausible energy intake reports on relationships between diet and BMI. Obes Res 2005; 13: 1205-17.

42. Krebs-Smith S, Braubard B, Kahle L, Subar A, Cleveland L, Ballard-Barbash R. Low energy reporters vs others: a comparison of reported food intakes. Eur J Clin Nutr 2000; 54: 281-7.

43. Macdiarmid J, Blundell J. Assessing dietary intake: who, what and why of under-reporting. Nutr Res Rev 1998; 11: 231-53.

44. Piernas C, Popkin BM. Trends in snacking among U.S. children. Health Aff (Millwood) 2010; 29: 398-404.

45. Dietary reference intakes for energy, carbohydrate, fiber, fat, fatty acids, cholesterol, protein, and amino acids. Panel on Macronutrients. National Academy of Sciences. Institute of Medicine of the National Academies. Washington, DC: National Academy Press; 2002.

46. Storey KE, Forbes LE, Fraser SN, Spence JC, Plotnikoff RC, Raine KD, et al. Diet quality, nutrition and physical activity among adolescents: the Web-SPAN (Web-Survey of Physical Activity and Nutrition) project. Public Health Nutr 2009; 12: 2009-17.

47. Marriott BP, Olsho L, Hadden L, Connor P. Intake of added sugars and selected nutrients in the United States, National Health and Nutrition Examination Survey (NHANES) 2003-2006. Crit Rev Food Sci Nutr 2010; 50: 228-58.

48. Frary CD, Johnson RK, Wang MQ. Children and adolescents' choices of foods and beverages high in added sugars are associated with intakes of key nutrients and food groups. $\mathbf{J}$ Adolesc Health 2004; 34: 56-63.

49. Joyce T, Gibney MJ. The impact of added sugar consumption on overall dietary quality in Irish children and teenagers. J Hum Nutr Diet 2008; 21: 438-50.

50. Kranz S, Smiciklas-Wright H, Siega-Riz AM, Mitchell D. Adverse effect of high added sugar consumption on dietary intake in American preschoolers. J Pediatr 2005; 146: 105-11.

51. Ruxton $\mathrm{CH}$, Gardner EJ, McNulty HM. Is sugar consumption detrimental to health? A review of the evidence 1995-2006. Crit Rev Food Sci Nutr 2010; 50: 1-19.

52. Livingstone MB, Rennie KL. Added sugars and micronutrient dilution. Obes Rev 2009; 10: 34-40.

53. Rusconi M, Conti A. Theobroma cacao L., the food of the gods: a scientific approach beyond myths and claims. Pharmacol Res 2010; 61: 5-13.

54. USDA. Agricultural Research Service. Nutrient Data Laboratory. http://www.nal.usda.gov/fnic/foodcomp/search [cited 16 July 2010].

55. Siri-Tarino PW, Sun Q, Hu FB, Krauss RM. Meta-analysis of prospective cohort studies evaluating the association of saturated fat with cardiovascular disease. Am J Clin Nutr 2010; 91: 535-46.

56. Costa GB, Horta N, Resende ZF, Souza G, Barreto LM, Correia LH, et al. Body mass index has a good correlation with proatherosclerotic profile in children and adolescents. Arq Bras Cardiol 2009; 93: 261-67.

57. Padilla FC, Liendo R, Quintana A. Characterization of cocoa butter extracted from hybrid cultivars of theobroma cacao $\mathrm{L}$. Arch Latinoam Nutr 2000; 50: 200-5.

58. Hunter JE, Zhang J, Kris-Etherton PM. Cardiovascular disease risk of dietary stearic acid compared with trans, other saturated, and unsaturated fatty acids: a systematic review. Am J Clin Nutr 2010; 91: 46-63.

59. Berry SE. Triacylglycerol structure and interesterification of palmitic and stearic acid-rich fats: an overview and implications for cardiovascular disease. Nutr Res Rev 2009; 22: 3-17.

60. Nicklas TA, Hayes D. American Dietetic Association. Position of the American Dietetic Association: nutrition guidance for healthy children ages 2 to 11 years. J Am Diet Assoc 2008; 108: 1038-44, 1046-47.

61. Hamed MS, Gambert S, Bliden KP, Bailon O, Singla A, Antonino MJ, et al. Dark chocolate effect on platelet activity, C-reactive protein and lipid profile: a pilot study. South Med J 2008; 101: 1203-8.

62. Baba S, Natsume M, Yasuda A, Nakamura Y, Tamura T, Osakabe $\mathrm{N}$, et al. Plasma LDL and HDL cholesterol and oxidized LDL concentrations are altered in normo- and hypercholesterolemic humans after intake of different levels of cocoa powder. J Nutr 2007; 137: 1436-41.

63. Jia L, Liu X, Bai YY, Li SH, Sun K, He C, et al. Short-term effect of cocoa product consumption on lipid profile: a metaanalysis of randomized controlled trials. Am J Clin Nutr 2010; 92: $218-25$.

64. Miller KB, Hurst WJ, Flannigan N, Ou B, Lee CY, Smith N, et al. Survey of commercially available chocolate- and cocoacontaining products in the United States. 2. Comparison of flavan-3-ol content with nonfat cocoa solids, total polyphenols, and percent cacao. J Agric Food Chem 2009; 57: 9169-80.

65. Miller KB, Stuart DA, Smith NL, Lee CY, McHale NL, Flanagan JA, et al. Antioxidant activity and polyphenol and procyanidin contents of selected commercially available cocoacontaining and chocolate products in the United States. J Agric Food Chem 2006; 54: 4062-68. 
66. Basch CE, Shea S, Arliss R, Contento IR, Rips J, Gutin B, et al Validation of mothers' reports of dietary intake by four to seven year-old children. Am J Public Health 1990; 80: 1314-17.

67. Baranowski T, Sprague D, Baranowski JH, Harrison JA. Accuracy of maternal dietary recall for preschool children. J Am Diet Assoc 1991; 91: 669-74.

68. Schoeller DA. How accurate is self-reported dietary energy intake? Nutr Rev 1990; 48: 373-9.

69. Champagne CM, Baker NB, DeLany JP, Harsha DW, Bray GA. Assessment of energy intake underreporting by doubly labeled water and observations on reported nutrient intakes in children. J Am Diet Assoc 1998; 98: 426-33.
70. Bandini LG, Schoeller DA, Cyr HN, Dietz WH. Validity of reported energy intake in obese and nonobese adolescents. Am J Clin Nutr 1990; 52: 421-5.

\section{*Carol E. O'Neil}

Class of 194I Alumni Professor

26I Knapp Hall

LSU AgCenter

Baton Rouge, Louisiana 70803, USA

Tel: 225-578-|63|

Fax: 225-578-4443

Email: coneil I@|su.edu 